\title{
Archaeal Community Structures in the Solfataric Acidic Hot Springs with Different Temperatures and Elemental Compositions
}

\author{
Tomoko Satoh, Keiko Watanabe, Hideo Yamamoto, \\ Shuichi Yamamoto, and Norio Kurosawa
}

Division of Environmental Engineering for Symbiosis, Graduate School of Engineering, Soka University, 1-236 Tangi-machi, Hachioji, Tokyo 192-8577, Japan

Correspondence should be addressed to Tomoko Satoh; stomoko76@soka.gr.jp

Received 31 October 2012; Revised 20 January 2013; Accepted 24 March 2013

Academic Editor: Yoshizumi Ishino

Copyright (C) 2013 Tomoko Satoh et al. This is an open access article distributed under the Creative Commons Attribution License, which permits unrestricted use, distribution, and reproduction in any medium, provided the original work is properly cited.

Archaeal 16S rRNA gene compositions and environmental factors of four distinct solfataric acidic hot springs in Kirishima, Japan were compared. The four ponds were selected by differences of temperature and total dissolved elemental concentration as follows: (1) Pond-A: $93^{\circ} \mathrm{C}$ and $1679 \mathrm{mg} \mathrm{L}^{-1}$, (2) Pond-B: $66^{\circ} \mathrm{C}$ and $2248 \mathrm{mg} \mathrm{L}^{-1}$, (3) Pond-C: $88^{\circ} \mathrm{C}$ and $198 \mathrm{mg} \mathrm{L}^{-1}$, and (4) Pond-D: $67^{\circ} \mathrm{C}$ and $340 \mathrm{mg} \mathrm{L}^{-1}$. In total, 431 clones of $16 \mathrm{~S}$ rRNA gene were classified into 26 phylotypes. In Pond-B, the archaeal diversity was the highest among the four, and the members of the order Sulfolobales were dominant. The Pond-D also showed relatively high diversity, and the most frequent group was uncultured thermoacidic spring clone group. In contrast to Pond-B and Pond-D, much less diverse archaeal clones were detected in Pond-A and Pond-C showing higher temperatures. However, dominant groups in these ponds were also different from each other. The members of the order Sulfolobales shared $89 \%$ of total clones in Pond-A, and the uncultured crenarchaeal groups shared $99 \%$ of total Pond-C clones. Therefore, species compositions and biodiversity were clearly different among the ponds showing different temperatures and dissolved elemental concentrations.

\section{Introduction}

The extreme environments are unique places to study how organisms interact with and adapt to the surroundings. Some of high temperature environments especially such as terrestrial hot springs and oceanic hydrothermal vents may resemble volcanic habitats that are thought to have existed on early Earth [1-3]. Indeed, some of the archaeal and bacterial lineages identified from hot springs appear to be related to lineages close to the root of the phylogenetic tree [4].

Hot spring microbial communities have been extensively studied in many areas such as Yellowstone National Park in the United States [5-10], Kamchatka hot springs in Russia [11], the island of the Lesser Antilles [12, 13], Icelandic hot springs [11, 14], Mt. Unzen hot springs in Japan [15], Ohwakudani hot springs in Japan [16], Pisciarelli hot springs in Italy [17], Bor Khlueng hot springs in Thailand [18], Wai-o-tapu geothermal area in New Zealand [19], and Tengchong hot springs in China [20]. These pioneering works enabled better appreciation of prokaryotic communities in the high temperature environments. However, despite decades of research, we still understand relatively little about the relationship between the environmental factors and hot spring prokaryotic community. It is important to reveal that which environmental factors affect prokaryotic community structures and diversity in individual hot spring habitats. Temperature has perhaps received the most attention, but other constraining factors may include $\mathrm{pH}$, oxidation redox potential, elemental composition, and organic matter composition. In this study, we compared the archaeal community structures and diversity of four distinct solfataric acidic hot springs in Kirishima, Japan.

\section{Materials and Methods}

2.1. Sample Collection and Analyses of Dissolved Elemental Compositions. The investigated hot springs in this study are located in a field of one square kilometer in the Kirishima 
TABLE 1: Characteristics of sampling sites and ponds.

\begin{tabular}{|c|c|c|c|c|c|c|c|c|}
\hline & \multicolumn{2}{|c|}{ Pond-A } & \multicolumn{2}{|c|}{ Pond-B } & \multicolumn{2}{|c|}{ Pond-C } & \multicolumn{2}{|c|}{ Pond-D } \\
\hline Temp $\left({ }^{\circ} \mathrm{C}\right)$ & \multicolumn{2}{|c|}{93} & \multicolumn{2}{|c|}{66} & \multicolumn{2}{|c|}{88} & \multicolumn{2}{|c|}{67} \\
\hline $\mathrm{pH}$ & \multicolumn{2}{|c|}{2.6} & \multicolumn{2}{|c|}{2.0} & \multicolumn{2}{|c|}{2.4} & \multicolumn{2}{|c|}{2.3} \\
\hline \multicolumn{9}{|c|}{ Concentration $\left(\mathrm{mg} \mathrm{L}^{-1}\right) /$ composition (\%) } \\
\hline $\mathrm{Fe}$ & 388.9 & 23 & 1149 & 51 & 9.630 & 5 & 27.18 & 8 \\
\hline$S$ & 663.2 & 40 & 702.8 & 31 & 59.76 & 30 & 61.90 & 18 \\
\hline $\mathrm{Al}$ & 433.6 & 26 & 287.9 & 13 & 14.57 & 7 & 2.021 & 1 \\
\hline $\mathrm{Mg}$ & 86.74 & 5 & 46.77 & 2 & 0.001 & 0 & 43.35 & 13 \\
\hline $\mathrm{Si}$ & 47.88 & 3 & 45.52 & 2 & 103.9 & 53 & 148.4 & 44 \\
\hline $\mathrm{Ca}$ & 54.81 & 3 & 10.88 & 0 & 7.498 & 4 & 39.26 & 12 \\
\hline $\mathrm{P}$ & 2.850 & 0 & 4.711 & 0 & 1.265 & 1 & 1.266 & 0 \\
\hline $\mathrm{Na}$ & 0.001 & 0 & 0.001 & 0 & 0.001 & 0 & 8.442 & 2 \\
\hline $\mathrm{K}$ & 0.001 & 0 & 0.001 & 0 & 0.001 & 0 & 7.384 & 2 \\
\hline As & 1.079 & 0 & 1.137 & 0 & 0.879 & 0 & 0.856 & 0 \\
\hline Total & 1679 & 100 & 2248 & 100 & 197.5 & 100 & 340.1 & 100 \\
\hline Latitude (N) & \multicolumn{2}{|c|}{$31^{\circ} 54^{\prime} 37.7^{\prime \prime}$} & \multicolumn{2}{|c|}{$31^{\circ} 54^{\prime} 52.4^{\prime \prime}$} & \multicolumn{2}{|c|}{$31^{\circ} 55^{\prime} 05.0^{\prime \prime}$} & \multicolumn{2}{|c|}{$31^{\circ} 55^{\prime} 04.5^{\prime \prime}$} \\
\hline Longitude (E) & \multicolumn{2}{|c|}{$130^{\circ} 49^{\prime} 00.6^{\prime \prime}$} & \multicolumn{2}{|c|}{$130^{\circ} 48^{\prime} 50.3^{\prime \prime}$} & \multicolumn{2}{|c|}{$130^{\circ} 48^{\prime} 41.1^{\prime \prime}$} & \multicolumn{2}{|c|}{$130^{\circ} 48^{\prime} 41.0^{\prime \prime}$} \\
\hline Altitude (m) & \multicolumn{2}{|c|}{759} & \multicolumn{2}{|c|}{842} & \multicolumn{2}{|c|}{884} & \multicolumn{2}{|c|}{885} \\
\hline Color of sediments & \multicolumn{2}{|c|}{ Light brown } & \multicolumn{2}{|c|}{ Light brown } & \multicolumn{2}{|c|}{ Gray } & \multicolumn{2}{|c|}{ Gray } \\
\hline
\end{tabular}

Detection limit is $0.001 \mathrm{mg} \mathrm{L}^{-1}$.

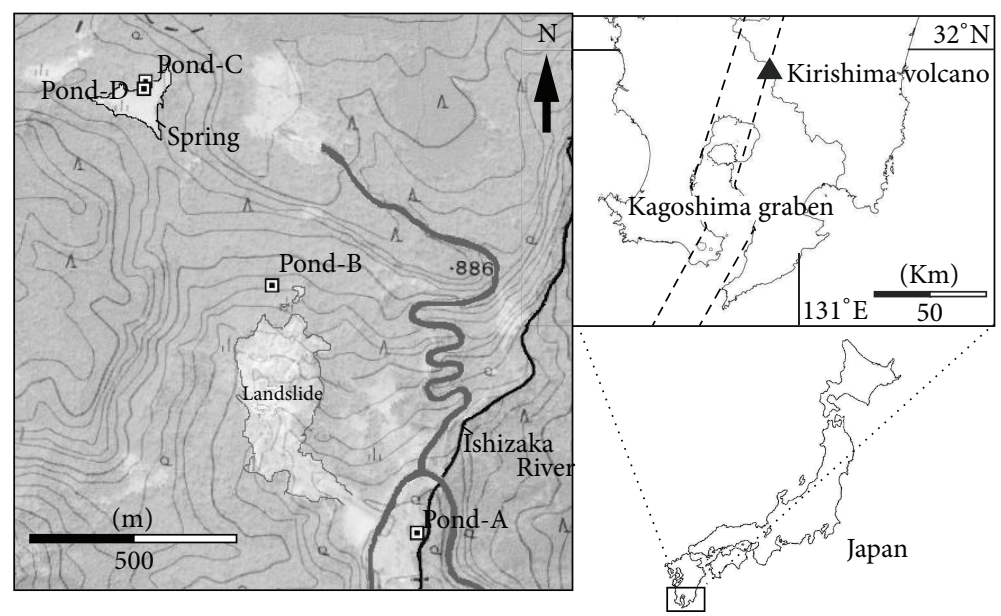

FIGURE 1: Map of sampling site in Kirishima geothermal area, Japan.

geothermal area in Japan (Kirishima National Park) (Figure 1, Table 1) where, the extensive volcanic activity occurred from the Pleistocene epoch to the present, depositing a thick pile of volcanic rocks [21]. Kirishima volcano, one of the largest Quaternary volcanoes in Japan, belongs to the northern part of the Kagoshima graben, a volcano-tectonic depression [22] caused by the subduction of the Philippine Sea plate. This volcano occupies an area of about $20 \mathrm{~km} \times 30 \mathrm{~km}$ elongated in the northwest to southeast direction and contains more than 20 small volcanoes [23].

Sampling location within Kirishima geothermal area is a private land; therefore, people are usually not allowed to trespass on this area. We got permission to take hot spring water, soil, and various other native samples in this area from an owner of the land. There are many hot springs and muddy ponds showing a variety of temperatures and elemental compositions.
Muddy water sample was collected into sterile $100 \mathrm{~mL}$ glass bottle at each pond. Temperature and $\mathrm{pH}$ of the samples were measured at each sampling site. A part of each sample was filtered using $0.22 \mu \mathrm{m}$ membrane filter (Asahi Glass) and was subjected to analysis of dissolved elemental concentrations using the inductively coupled plasma optical emission spectroscopy (ICPS-7000 ver.2, Shimadzu). In the present study, we selected four ponds displaying a range of temperatures and dissolved elemental compositions for the archaeal community analysis.

2.2. 16S rRNA Gene Clone Libraries and Sequencing. The environmental DNA was extracted from 5 to $10 \mathrm{~g}$ of each muddy water sample using the UltraClean Soil DNA Kit Mega Prep (Mo Bio Laboratories) according to the manufacturer's instructions. The precipitated DNA was purified 
using the GFX PCR DNA and Gel Band Purification Kit (GE Healthcare).

Purified DNA was used as the template for the amplification of archaeal 16S rRNA gene by archaea-specific primer A21F: $5^{\prime}$-TTCCGGTTGATCCYGCCGGA and universal primer U1492R: 5'-GGYTACCTTGTTACGACTT. The PCR conditions included an initial denaturation step at $94^{\circ} \mathrm{C}$ for $3 \mathrm{~min}$, followed by 35 cycles of denaturation at $94^{\circ} \mathrm{C}$ for $30 \mathrm{sec}$, annealing at $55^{\circ} \mathrm{C}$ for $30 \mathrm{sec}$, and extension at $72^{\circ} \mathrm{C}$ for 2 min using Ex Taq DNA polymerase (Takara Bio). This was followed by a final extension at $72^{\circ} \mathrm{C}$ for $10 \mathrm{~min}$.

The PCR products were purified using the aforementioned GFX Kit and were ligated into the pT7 Blue T-Vector (Novagen). E. coli $\mathrm{DH} 5 \alpha$ cells were transformed with the plasmid library and were plated onto LB plates including $100 \mu \mathrm{g} \mathrm{mL}^{-1}$ ampicillin, $40 \mu \mathrm{g} \mathrm{mL}^{-1} \mathrm{X}$-gal, and $0.5 \mathrm{mM}$ IPTG. Blue/white selection was conducted by randomly picking and subculturing individual white colonies in $100 \mu \mathrm{L}$ of $2 \times$ YT medium containing $100 \mu \mathrm{g} \mathrm{mL}^{-1}$ ampicillin in a 96-well plate at $37^{\circ} \mathrm{C}$ overnight. The inserted $16 \mathrm{~S}$ rRNA gene was amplified using $1 \mu \mathrm{L}$ of the culture as the template with the same PCR procedure mentioned above. About $800 \mathrm{bp}$ of the $5^{\prime}$-region of each $16 \mathrm{~S}$ rRNA gene clone was sequenced by the aforementioned archaea-specific primer A21F and used for taxonomic and phylogenetic analysis.

2.3. Identification of $16 S$ rRNA Gene Clones and Phylogenetic Analysis. 16S rRNA gene sequences were edited using the MEGA5 (Molecular Evolutionary Genetics Analysis, http://www.megasoftware.net/) [24]. We also searched for chimera sequences by manually checking the sequence alignments using GENETYX ver. 10.0.3 software (Genetyx). Clones having $97 \%$ sequence similarity or higher were treated as a phylotype. The representative sequences of each phylotype were compared with $16 \mathrm{~S}$ rRNA gene sequences published in the National Center for Biotechnology Information DNA database using BLAST (BLASTN; http://www.ncbi.nlm.nih.gov/BLAST/) [25] to identify individual clones. The representative sequences of each phylotype and related sequences in the GenBank data base were aligned using CLUSTALW ver. 1.83 program [26]. The maximum likelihood tree including bootstrap probabilities (1000 samplings) was constructed using the MEGA5.

2.4. Statistical Analyses. Measurements of diversity ideally include richness, the number of different species or groups present, and evenness, the distribution of those groups [27, 28]. The Shannon-Weaver index [29], $H^{\prime}=-\Sigma(p i)(\ln p i)$, and Simpson's reciprocal index [30], $1 / D$, where $D=\Sigma(p i)^{2}$, and $p i$ is the proportion of phylotypes $i$ relative to the total number of phylotypes, both take richness and evenness into account $[13,28]$. The Shannon-Weaver index and Simpson's reciprocal index were calculated using ESTIMATES 8.0 [31]. Evenness $\left(J^{\prime}=H^{\prime} / \ln S\right)$ was also calculated [32]. ESTIMATES 8.0 was also used to calculate Chaol nonparametric richness estimator [33] and abundance-based coverage estimator of species richness (ACE) [34]. These coverage estimators determine the number of probable phylotypes in the environment compared with the numbers observed in the sample. The homologous coverage (biodiversity coverage) $C$ was determined with the following equation: $C=1-(N / n)$, where $N$ is the number of phylotypes sequences and $n$ is the total number of analyzed clones [35, 36]. Additionally, statistical analyses including principal components analysis to determine the correlations among the archaeal diversity with the environmental factors including temperature and dissolved elemental concentrations. Canonical correlation analysis was also performed to determine the correlations between archaeal groups and temperature or dissolved elemental concentrations, by using the software XLSTAT (Addinsoft, New York, NY).

2.5. Nucleotide Sequence Accession Numbers. The representatives of nucleotide sequences of the phylotypes are available in the DDBJ/EMBL/GenBank databases under the accession numbers AB753272-AB753298 and AB755799-AB755806.

\section{Results and Discussion}

3.1. Water Chemistry. The four ponds in Kirishima geothermal area were selected based on the differences of temperatures and total dissolved elemental concentrations as follows: (1) Pond-A: $93^{\circ} \mathrm{C}$ and $1679 \mathrm{mg} \mathrm{L}^{-1}$, (2) Pond-B: $66^{\circ} \mathrm{C}$ and $2248 \mathrm{mg} \mathrm{L}^{-1}$, (3) Pond-C: $88^{\circ} \mathrm{C}^{\text {and }} 198 \mathrm{mg} \mathrm{L}^{-1}$, and (4) PondD: $67^{\circ} \mathrm{C}$ and $340 \mathrm{mg} \mathrm{L}^{-1}$. The characteristics of sampling sites and these ponds are shown in Table 1 . The range of $\mathrm{pH}$ values of the ponds was 2.0-2.6. In the ponds showing higher total dissolved elemental concentration, the concentrations and percentages of $\mathrm{Fe}, \mathrm{S}$, and $\mathrm{Al}$ were especially higher than those in other ponds. There was no significant difference of the concentrations of $\mathrm{Mg}, \mathrm{Si}, \mathrm{Ca}, \mathrm{P}, \mathrm{Na}, \mathrm{K}$, and as between the ponds.

3.2. $16 \mathrm{~S}$ rRNA Gene Clone Libraries. $16 \mathrm{~S}$ rRNA gene clone libraries were successfully constructed using the environmental DNAs extracted from four muddy water samples. A total of 432 clones of archaeal 16S rRNA gene were analyzed. A chimerical sequence was detected during the analysis and was not used for further study. On the basis of the sequence similarity values, a total of 431 clones (Pond-A: 106, PondB: 112, Pond-C: 109, and Pond-D: 104 clones) were classified into 26 phylotypes, consisting of 25 crenarchaeal phylotypes and a single euryarchaeal one (Table 2). The homologous coverage values were 0.88 or above for all ponds indicating that approximately $90 \%$ of the $16 \mathrm{~S}$ rRNA gene clones in these ponds could be considered in this study (Table 3 ).

The guanine-plus-cytosine $(\mathrm{G}+\mathrm{C})$ content in the $16 \mathrm{~S}$ rRNA gene sequences detected from 26 phylotypes in this study ranged from $56.6 \%$ to $69.0 \%$, with an overall average of $62.4 \pm 3.6 \%$. According to Kimura et al., the growth temperature of archaea are strongly correlated with the $\mathrm{G}+$ $\mathrm{C}$ content, while the phylotypes containing this amount of $\mathrm{G}+\mathrm{C}$ were grouped as the moderately thermophilic and hyperthermophilic archaea [37]. Therefore, all phylotypes detected in this study could possibly be related to moderately thermophilic and hyperthermophilic archaea. 
TABLE 2: Affiliation and closest published species or clones of 26 phylotypes.

\begin{tabular}{|c|c|c|c|c|c|c|c|}
\hline \multirow[t]{2}{*}{ Phylotypes } & \multirow[t]{2}{*}{ Affiliation } & \multirow{2}{*}{$\begin{array}{l}\text { Closest species or clones } \\
\text { (accession number) }\end{array}$} & \multirow{2}{*}{$\begin{array}{c}\text { 16S rRNA gene } \\
\text { similarity } \\
(\%)\end{array}$} & \multicolumn{4}{|c|}{ Number of clones detected from each site } \\
\hline & & & & Pond-A & Pond-B & Pond-C & Pond-D \\
\hline \multicolumn{8}{|c|}{ Order Sulfolobales } \\
\hline ST2A1-3 & Acidianus brierleyi & Acidianus brierleyi (D26489) & 98.9 & & 3 & & \\
\hline ST2A1-43 & Acidianus sp. & Acidianus ambivalens (D85506) & 95.5 & & 1 & & \\
\hline ST2A1-14 & Metallosphaera sedula & Metallosphaera sedula (D26491) & 100.0 & & 7 & & \\
\hline ST2A1-16 & Sulfolobus solfataricus & Sulfolobus solfataricus (D26490) & 99.1 & & 2 & & \\
\hline ST8A1-57 & Sulfurisphaera sp. & $\begin{array}{l}\text { Sulfurisphaera ohwakuensis } \\
\text { (D85507) }\end{array}$ & 95.1 & 1 & & & \\
\hline ST2A1-5 & Uncultured Sulfolobales & $\begin{array}{l}\text { Acidic hot spring clone } \\
\text { HO78W21A35 (AB600386) }\end{array}$ & 80.7 & & 39 & & \\
\hline ST2A1-32 & Uncultured Sulfolobales & $\begin{array}{l}\text { Acidic sulfuric hot spring clone } \\
\text { LH2wa_90 (FJ797343) }\end{array}$ & 98.3 & & 6 & & \\
\hline ST8A1-12 & Uncultured Sulfolobales & $\begin{array}{l}\text { Acidic sulfuric hot spring clone } \\
\text { HS3wa_52 (FJ797311) }\end{array}$ & 96.6 & 92 & & & \\
\hline ST8A1-52 & Uncultured Sulfolobales & $\begin{array}{c}\text { Acidic sulfuric hot spring clone } \\
\text { HS3wa_52 (FJ797311) }\end{array}$ & 94.1 & 1 & & & \\
\hline \multicolumn{8}{|c|}{ Order Acidilobales } \\
\hline ST2A1-9 & Caldisphaera lagunensis & $\begin{array}{l}\text { Caldisphaera lagunensis } \\
\text { (AB087499) }\end{array}$ & 98.5 & & 10 & & \\
\hline ST2A1-27 & Caldisphaera sp. & $\begin{array}{l}\text { Caldisphaera draconis } \\
\text { (EF057392) }\end{array}$ & 95.4 & & 2 & & 21 \\
\hline \multicolumn{8}{|l|}{$(=\mathrm{ST} 15 \mathrm{~A} 1-7)$} \\
\hline \multicolumn{8}{|c|}{ Order Thermoproteales } \\
\hline ST8A1-8 & Caldivirga maquilingensis & $\begin{array}{l}\text { Caldivirga maquilingensis } \\
\text { (AB013926) }\end{array}$ & 98.0 & 5 & 2 & & \\
\hline \multicolumn{8}{|l|}{$(=\mathrm{ST} 2 \mathrm{~A} 1-31)$} \\
\hline ST8A1-40 & Vulcanisaeta distributa & $\begin{array}{l}\text { Vulcanisaeta distributa } \\
(\mathrm{AB} 063630)\end{array}$ & 98.9 & 7 & & & \\
\hline ST16A1-87 & Thermocladium modestius & $\begin{array}{c}\text { Thermocladium modestius } \\
\text { (AB005296) }\end{array}$ & 99.4 & & & 1 & \\
\hline \multicolumn{8}{|c|}{ Other crenarchaeal groups } \\
\hline ST2A1-8 & UTSCG & $\begin{array}{l}\text { Acidic sulfuric hot spring clone } \\
\text { LH2wa_02 (FJ797332) }\end{array}$ & 99.7 & & 20 & 42 & 52 \\
\hline \multicolumn{8}{|l|}{$\begin{array}{l}(=\text { ST16A1-1, } \\
\text { ST15A1-1) }\end{array}$} \\
\hline ST15A1-3 & UTSCG & $\begin{array}{l}\text { Acidic hot spring clone } \\
\text { Uzon4-5d (HQ395709) }\end{array}$ & 96.1 & & & & 2 \\
\hline ST16A1-6 & UTSCG & $\begin{array}{l}\text { Acidic spring clone HO28S9A21 } \\
\text { (AB600335) }\end{array}$ & 96.9 & & & 6 & \\
\hline ST16A1-20 & UTSCG & $\begin{array}{c}\text { Hot spring clone SK865 } \\
\text { (DQ834117) }\end{array}$ & 96.9 & & & 13 & 6 \\
\hline \multicolumn{8}{|l|}{$(=\mathrm{ST} 15 \mathrm{~A} 1-6)$} \\
\hline ST2A1-2 & UTSCG II & $\begin{array}{l}\text { Hot spring clone BW303 } \\
\text { (DQ924843) }\end{array}$ & 93.3 & & 4 & & \\
\hline ST2A1-15 & UTSCG II & $\begin{array}{l}\text { Hot spring clone SK993 } \\
\text { (DQ834245) }\end{array}$ & 99.7 & & 1 & & \\
\hline ST15A1-26 & HWCG V & $\begin{array}{l}\text { Acidic spring clone HO28S9A51 } \\
\text { (AB600343) }\end{array}$ & 96.3 & & & & 1 \\
\hline ST15A2-137 & HWCG V & $\begin{array}{l}\text { Acidic spring clone HO28S9A51 } \\
\text { (AB600343) }\end{array}$ & 98.4 & & & & 2 \\
\hline
\end{tabular}


TABLE 2: Continued.

\begin{tabular}{|c|c|c|c|c|c|c|c|}
\hline \multirow[t]{2}{*}{ Phylotypes } & \multirow[t]{2}{*}{ Affiliation } & \multirow[t]{2}{*}{$\begin{array}{l}\text { Closest species or clones } \\
\text { (accession number) }\end{array}$} & \multirow{2}{*}{$\begin{array}{c}\text { 16S rRNA gene } \\
\text { similarity } \\
(\%)\end{array}$} & \multicolumn{4}{|c|}{ Number of clones detected from each site } \\
\hline & & & & Pond-A & Pond-B & Pond-C & Pond-D \\
\hline ST2A1-25 & HWCG VI & $\begin{array}{l}\text { Hot spring clone SK859 } \\
\text { (DQ834111) }\end{array}$ & 95.8 & & 13 & 46 & 2 \\
\hline \multicolumn{8}{|l|}{$\begin{array}{l}(=\text { ST16A1-2, } \\
\text { ST15A1-34) }\end{array}$} \\
\hline ST2A1-52 & HWCG VI & $\begin{array}{l}\text { Hot spring clone SK859 } \\
\text { (DQ834111) }\end{array}$ & 96.0 & & 2 & & \\
\hline ST15A1-32 & HWCG VII & $\begin{array}{c}\text { Acidic sulfuric hot spring clone } \\
\text { HS4sa_15 (FJ797318) }\end{array}$ & 91.2 & & & & 1 \\
\hline \multicolumn{8}{|c|}{ Euryarchaeal groups } \\
\hline $\begin{array}{l}\text { ST16A1-50 } \\
(=\text { ST15A1-8) }\end{array}$ & $\begin{array}{l}\text { Uncultured } \\
\text { Euryarchaeota }\end{array}$ & $\begin{array}{l}\text { Thermal spring clone kmc048 } \\
\text { (HM150106) }\end{array}$ & 99.2 & & & 1 & 17 \\
\hline Total & & & & 106 & 112 & 109 & 104 \\
\hline
\end{tabular}

TABLE 3: Diversity index scores for clone libraries.

\begin{tabular}{|c|c|c|c|c|c|c|c|c|}
\hline Sample & Shannon & Simpson & Rich & Even & $S_{\mathrm{ACE}}$ & $S_{\text {Chaol }}$ & Coverage & Total clone number \\
\hline Pond-A & 0.53 & 1.32 & 5 & 0.332 & 7.04 & 6.00 & 0.95 & 106 \\
\hline Pond-B & 2.06 & 5.41 & 14 & 0.780 & 15.4 & 14.2 & 0.88 & 112 \\
\hline Pond-C & 1.23 & 2.91 & 6 & 0.687 & 10.1 & 7.00 & 0.94 & 109 \\
\hline Pond-D & 1.45 & 3.10 & 9 & 0.659 & 10.9 & 9.25 & 0.91 & 104 \\
\hline $\begin{array}{l}\text { Temperature } \\
\text { approximately } 90^{\circ} \mathrm{C} \\
\text { (Pond-A + Pond-C) }\end{array}$ & 1.58 & 3.66 & 11 & 0.659 & 16.0 & 17.0 & 0.95 & 215 \\
\hline $\begin{array}{l}\text { Temperature } \\
\text { approximately } 70^{\circ} \mathrm{C} \\
\text { (Pond-B + Pond-D) }\end{array}$ & 2.20 & 5.82 & 20 & 0.735 & 23.3 & 21.0 & 0.91 & 216 \\
\hline $\begin{array}{l}\text { El. conc. > } 1600 \text { ppm } \\
\text { (Pond-A + Pond-B) }\end{array}$ & 1.99 & 4.37 & 18 & 0.689 & 21.0 & 19.5 & 0.92 & 218 \\
\hline $\begin{array}{l}\text { El. conc. }<350 \text { ppm } \\
(\text { Pond-C + Pond-D) }\end{array}$ & 1.61 & 3.68 & 11 & 0.673 & 15.5 & 13.3 & 0.95 & 213 \\
\hline
\end{tabular}

Diversity index scores measured were Shannon-Weaver index (Shannon), Simpson's reciprocal index (Simpson), Richness (Rich), Evenness (Even), the coverage estimators $S_{\mathrm{ACE}}$ and $S_{\mathrm{Chaol}}$, and the homologous coverage. El. conc. indicates total dissolved elemental concentration.

3.3. Archaeal Community in Pond-A. On the basis of $16 \mathrm{~S}$ rRNA gene sequence similarities, 106 clones derived from Pond-A which showed higher temperature and total dissolved elemental concentration consisted of five phylotypes of Crenarchaeota (Table 2). The 5\% and 7\% sequences of this pond were highly similar to those of cultured species $(>98.0 \%)$ of the order Thermoproteales, Caldivirga maquilingensis and Vulcanisaeta distributa, respectively. The type strains of both species were hyperthermophilic archaea optimally growing at above $85^{\circ} \mathrm{C}$, and they were originally isolated from acidic hot springs in Philippines and Japan, respectively [38,39]. On the other hand, other $89 \%$ of Pond-A clones did not show significant similarities with any cultured species. Almost all the clones of them were assigned as a phylotype ST8A1-12 affiliated with the order Sulfolobales. This phylotype showed $95-96 \%$ sequence similarity with published environmental clones, NAKO74-07 and HS3wa_52 detected from Nakabusa hot spring, Japan (DNA database
Accession no. AB366602) [37] and Tatung Volcano hot spring, Taiwan (DNA database Accession no. FJ797311). The diversity represented by the Shannon-Weaver index and Simpson's reciprocal index in the Pond-A was the lowest among the four ponds (Table 3).

3.4. Archaeal Community in Pond-B. In contrast to the Pond$A$, the largest number of phylotypes was detected in Pond$B$ which was characterized as lower temperature and higher total dissolved elemental concentration, resulting, that the diversity indices and evenness value in this pond were highest among the four ponds (Table 3 ). A total of 112 clones consisted of 14 phylotypes that were classified into the following six groups: the order Sulfolobales, Acidilobales, Thermoproteales, and three uncultured crenarchaeal groups (Table 2, Figure 2). The $21 \%$ of the total clones were closely related to any of five cultured species ( $>98.0 \%)$ : Sulfolobus solfataricus [40], Metallosphaera sedula [41], Acidianus brierleyi [42], 
Caldisphaera lagunensis [43], and Caldivirga maquilingensis [38]. S. solfataricus, M. sedula, and A. brierleyi are facultatively chemolithoautotrophic aerobes and require elemental sulfur or sulfidic ores. These species and their close relatives have been isolated from acidic Solfatara fields around the world [44]. C. lagunensis and C. maquilingensis are heterotrophic anaerobes. Their growths are stimulated or constrained by the presence of sulfur as an electron acceptor.

On the other hand, nine phylotypes sharing $79 \%$ in total of all Pond-B clones showed no significant similarity with any cultured species. Nearly half of these uncultured clones were assigned as a phylotype ST2A1-5. This phylotype was most dominant $(35 \%)$ in Pond-B and was phylogenetically distant not only from any cultured species but also from any published environmental clones. This novel phylotype belonged to a cluster in the order Sulfolobales (Figure 2). This cluster also harbored another Pond-B phylotype ST2A1-32, which showed 98\% 16S rRNA gene sequence similarity with published environmental clone, LH2wa_90 detected from Taiwanese hot spring (DNA database Acc. no. FJ797343).

The phylotype ST2A1-8 belonging to the uncultured thermoacidic spring clone group (UTSCG) [16] was secondary dominant in Pond-B and it shared $18 \%$ of the total PondB clones. Interestingly, phylotypes similar to ST2A1-8 were also frequently detected in Pond-C and Pond-D, suggesting that this crenarchaeal species survive relatively wide range of temperature and dissolved elemental composition in acidic hot springs. There might be unfavorable factors in Pond-A for the presence of UTSCG. The phylotypes ST2A1-2 and ST2A1-15 were placed in the sister cluster of UTSCG with published clones detected from Yellowstone National Park (DNA database Acc. no. DQ834245). We call this cluster as UTSCG II in this study.

The phylotype ST2A1-25 was thirdly dominant in Pond$\mathrm{B}$ and was placed into the sister cluster of the hot water crenarchaeotic group II (HWCG II) $[15,45,46]$ with phylotype ST2A1-52 and published environmental clone SK859 detected from acidic hot spring in Yellowstone National Park (DNA database Acc. No. DQ834111). We call this cluster as HWCG VI in this study. The phylotype ST2A1-25 was also dominant in Pond-C.

3.5. Archaeal Community in Pond-C. The other high temperature pond, Pond-C, showed relatively low value of species richness as same as Pond-A (Table 3). A hundred and nine clones were classified into six phylotypes as follows: Thermocladium modestius of the order Thermoproteales, four uncultured crenarchaeal phylotypes and uncultured euryarchaeal phylotypes. The type strain of T. modestius was originally isolated from solfataric mud at Noji-onsen, Japan, and is an anaerobic heterotroph growing optimally around $75^{\circ} \mathrm{C}, \mathrm{pH} 4.0$ [47].

As mentioned in the previous section, the uncultured phylotypes ST2A1-8 of UTSCG and ST2A1-25 of HWCG VI were dominant in the clone library constructed for this pond sample. These two phylotypes shared $81 \%$ in total of the PondC clones. Three phylotypes sharing 56\% of Pond-C clones were affiliated with uncultured thermoacidic spring clone group (UTSCG) [16].
3.6. Archaeal Community in Pond-D. A hundred and four clones derived from Pond-D which showed lower temperature and total dissolved elemental concentration consisted of nine phylotypes. The diversity indices in Pond-D were lower than those in Pond-B but were higher than the values in Pond-A and Pond-C (Table 3). The phylotype sharing $20 \%$ of the total clones was related to Caldisphaera draconis with $95 \%$ sequence similarity of $16 \mathrm{~S}$ rRNA gene. This species is chemoorganotrophic anaerobe isolated from acidic hot spring in Yellowstone National Park [48].

Other phylotypes showed no significant similarity with any cultured species. The most frequent phylotype was ST2A1-8 affiliated with UTSCG and it shared $50 \%$ of the total clone in this pond. In contrast to the archaeal communities in other three ponds, the secondary dominant uncultured phylotype (ST16A1-50) was affiliated with Euryarchaeota and showed 99\% sequence similarity of $16 \mathrm{~S}$ rRNA gene with thermal spring clone kmc048 detected from Kamchatka hot springs in Russia (DNA database Acc. no. HM150106). This phylotype shared $16 \%$ of the total clones in this pond.

The phylotype ST15A1-26 together with ST15A2-137 and ST15A1-32 were barely detected in Pond-D, and were placed into the sister cluster of HWCG II. We call these clusters as HWCG V and HWCG VII, respectively, in this study.

3.7. Archaeal Diversity and Community Structures with Different Temperatures and Total Dissolved Elemental Concentrations. When the diversity was compared within ponds with different temperatures (Temperature approximately $90^{\circ} \mathrm{C}$, Pond-A + Pond-C versus Temp. approx. $70^{\circ} \mathrm{C}$, Pond- $\mathrm{B}+$ Pond-D), represented by the Shannon-Weaver index and Simpson's reciprocal index, the lower temperature ponds showed higher diversity (Table 3). On the other hand, when comparing within ponds with different total dissolved elemental concentrations, the diversity indices of higher total dissolved elemental concentration ponds (El. conc. > $1600 \mathrm{mg} \mathrm{L}^{-1}$, Pond-A + Pond-B), were higher than those of Pond-C + Pond-D (El. conc. $<350 \mathrm{mg} \mathrm{L}^{-1}$ ). As a result, the archaeal diversity was the highest in the pond characterized as lower temperature and higher total dissolved elemental concentration (Pond-B). In contrast, the combination of higher temperature and lower total dissolved elemental concentration (Pond-A) caused the lowest diversity in this study.

When focusing on the species composition and distribution, they were dissimilarity within ponds with different temperatures and total dissolved elemental concentrations. As shown in Table 2, the phylotypes affiliated with the order Sulfolobales were only detected in the ponds showing higher total dissolved elemental concentrations (Pond-A + Pond-B). The members of the order Sulfolobales are generally characterized as facultatively or obligately chemolithoautotrophic $S^{0}$ metabolizers; some members oxidize ferrous iron and sulfidic ores, producing soluble metal sulfates [44]. Therefore, the presence of Sulfolobales makes sense in these ponds including higher total dissolved elemental concentration, especially sulfur, as we would expect to detect microbes 


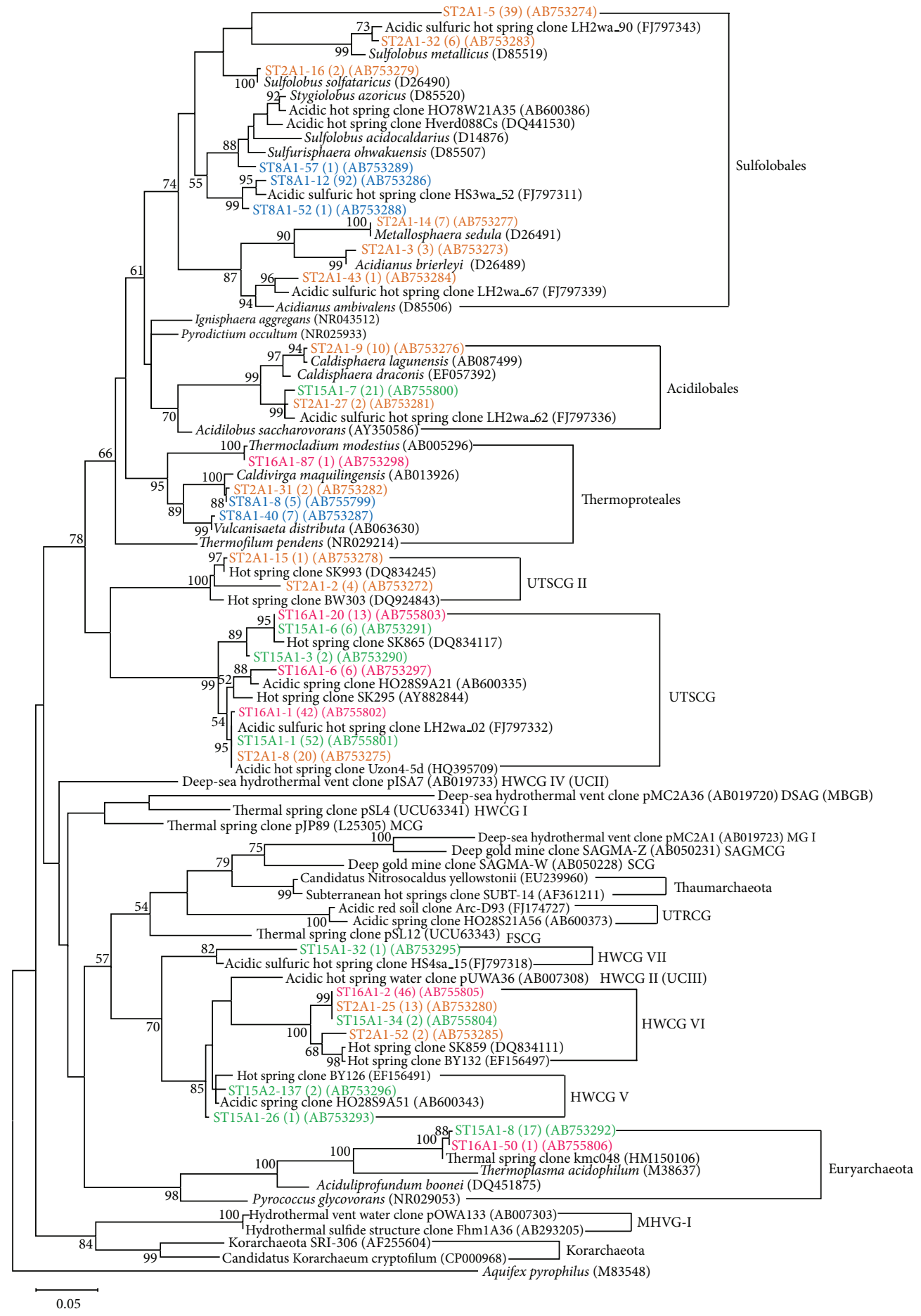

FIGURE 2: Phylogenetic tree of archaeal 16S rRNA gene sequences detected in Kirishima hot springs. Bootstrap values ( $>50 \%)$ based on 1000 replicates are indicated at nodes. The scale bar indicates the number of nucleotide substitutions per position. Number in the parenthesis with phylotype name represents the number of clones of each phylotype. The DNA database accession numbers are also indicated in the parenthesis. Aquifex pyrophilus is used as an outgroup species. The phylotype names derived from Pond-A, Pond-B, Pond-C, and Pond-D shown in blue, yellow, red, and green, respectively. UTSCG: uncultured thermoacidic spring clone group [16], HWCG I: hot water crenarchaeotic group I [6, 46], HWCG II (known as UCIII): uncultured crenarchaeal group III [15, 45, 46], HWCG IV (also known as UCII) [45, 49, 50], DSAG (known as MBGB): deep-sea archaeal group (marine benthic group B) [49, 51], MCG: miscellaneous crenarchaeal group [5, 50, 52, 53], MG I: marine crenarchaeotic group I [49, 54], SAGMCG: South Africa gold mine group [52], SCG: soil crenarchaeotic group [52], UTRCG: uncultured Thaumarchaeota-related clone group [16], FSCG: forest soil crenarchaeotic group [6, 55], and MHVG-I: marine hydrothermal vent group I $[15,16,52]$. 
TABLE 4: Correlation matrix showing $r$ values for Pearson's correlation.

\begin{tabular}{lcccccccccccccc}
\hline Variables & Shannon & $\mathrm{Temp}$. & $\mathrm{Fe}$ & $\mathrm{S}$ & $\mathrm{Al}$ & $\mathrm{Mg}$ & $\mathrm{Si}$ & $\mathrm{Ca}$ & $\mathrm{P}$ & $\mathrm{Na}$ & $\mathrm{K}$ & $\mathrm{As}$ & $\mathrm{El}$. Conc. \\
\hline Shannon & $\mathbf{1 . 0 0}$ & -0.87 & 0.54 & 0.00 & -0.32 & -0.41 & 0.07 & -0.71 & 0.42 & 0.14 & 0.14 & 0.11 & 0.20 \\
Temp. & -0.87 & $\mathbf{1 . 0 0}$ & -0.40 & 0.05 & 0.31 & 0.12 & -0.29 & 0.29 & -0.29 & -0.55 & -0.55 & -0.01 & -0.14 \\
$\mathrm{Fe}$ & 0.54 & -0.40 & $\mathbf{1 . 0 0}$ & 0.84 & 0.62 & 0.34 & -0.76 & -0.26 & $\mathbf{0 . 9 9}$ & -0.46 & -0.46 & $\mathbf{0 . 9 0}$ & $\mathbf{0 . 9 2}$ \\
$\mathrm{S}$ & 0.00 & 0.05 & 0.84 & $\mathbf{1 . 0 0}$ & $\mathbf{0 . 9 5}$ & 0.71 & $-\mathbf{0 . 9 3}$ & 0.21 & $\mathbf{0 . 9 1}$ & -0.57 & -0.57 & $\mathbf{0 . 9 9}$ & $\mathbf{0 . 9 8}$ \\
$\mathrm{Al}$ & -0.32 & 0.31 & 0.62 & $\mathbf{0 . 9 5}$ & $\mathbf{1 . 0 0}$ & 0.82 & $-\mathbf{0 . 9 0}$ & 0.44 & 0.72 & -0.57 & -0.57 & $\mathbf{0 . 9 0}$ & 0.87 \\
$\mathrm{Mg}$ & -0.41 & 0.12 & 0.34 & 0.71 & 0.82 & $\mathbf{1 . 0 0}$ & -0.49 & 0.82 & 0.44 & -0.02 & -0.02 & 0.61 & 0.64 \\
$\mathrm{Si}$ & 0.07 & -0.29 & -0.76 & $-\mathbf{0 . 9 3}$ & $-\mathbf{0 . 9 0}$ & -0.49 & $\mathbf{1 . 0 0}$ & 0.00 & -0.83 & 0.84 & 0.84 & $-\mathbf{0 . 9 4}$ & -0.89 \\
$\mathrm{Ca}$ & -0.71 & 0.29 & -0.26 & 0.21 & 0.44 & 0.82 & 0.00 & $\mathbf{1 . 0 0}$ & -0.15 & 0.33 & 0.33 & 0.07 & 0.08 \\
$\mathrm{P}$ & 0.42 & -0.29 & $\mathbf{0 . 9 9}$ & $\mathbf{0 . 9 1}$ & 0.72 & 0.44 & -0.83 & -0.15 & $\mathbf{1 . 0 0}$ & -0.51 & -0.51 & $\mathbf{0 . 9 5}$ & $\mathbf{0 . 9 7}$ \\
$\mathrm{Na}$ & 0.14 & -0.55 & -0.46 & -0.57 & -0.57 & -0.02 & 0.84 & 0.33 & -0.51 & $\mathbf{1 . 0 0}$ & $\mathbf{1 . 0 0}$ & -0.62 & -0.51 \\
$\mathrm{~K}$ & 0.14 & -0.55 & -0.46 & -0.57 & -0.57 & -0.02 & 0.84 & 0.33 & -0.51 & $\mathbf{1 . 0 0}$ & $\mathbf{1 . 0 0}$ & -0.62 & -0.51 \\
$\mathrm{As}$ & 0.11 & -0.01 & $\mathbf{0 . 9 0}$ & $\mathbf{0 . 9 9}$ & $\mathbf{0 . 9 0}$ & 0.61 & $-\mathbf{0 . 9 4}$ & 0.07 & $\mathbf{0 . 9 5}$ & -0.62 & -0.62 & $\mathbf{1 . 0 0}$ & $\mathbf{0 . 9 9}$ \\
El. conc. & 0.20 & -0.14 & $\mathbf{0 . 9 2}$ & $\mathbf{0 . 9 8}$ & 0.87 & 0.64 & -0.89 & 0.08 & $\mathbf{0 . 9 7}$ & -0.51 & -0.51 & $\mathbf{0 . 9 9}$ & $\mathbf{1 . 0 0}$ \\
\hline
\end{tabular}

Values in bold are different from 0 with a significance level $\alpha=0.10$. Diversity indices showed very similar correlations with each other and environmental variables: only Shannon-Weaver index for archaeal clone libraries is shown. Shannon, Temp. and El. Conc. indicate Shannon-Weaver index, Temperature, and total dissolved elemental concentration, respectively.

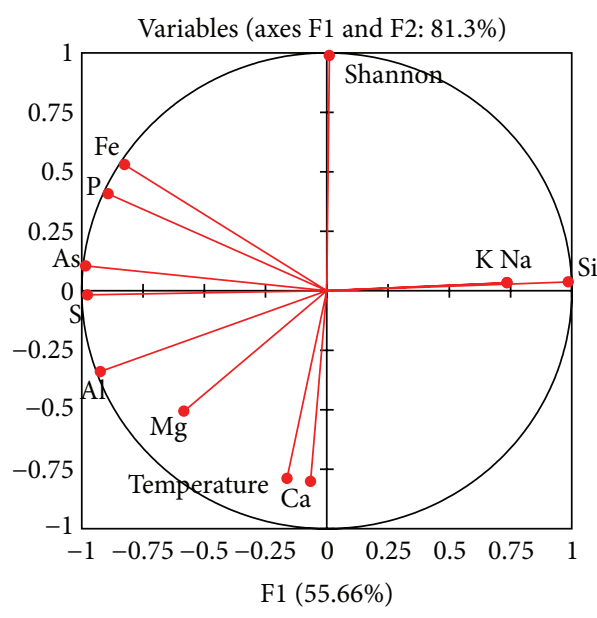

(a)

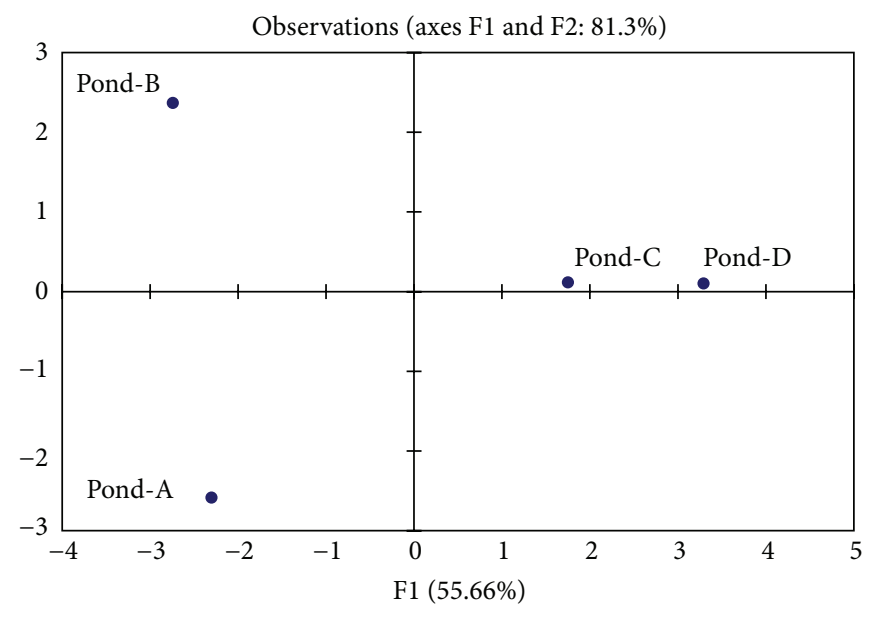

(b)

Figure 3: Principal components analysis showing loadings on principal components 1 and 2 for environmental factors at sites and the relationship to each site. Shannon, Temp. and El. Conc. indicate Shannon-Weaver index, temperature, and total dissolved elemental concentration, respectively.

that metabolically depend on sulfur as an electron donor. It is also interesting that the species compositions within the order Sulfolobales between Pond-A and Pond-B were clearly different from each other. We detected sequences closely related to Sulfolobales species (98.9\% similarity) in Pond-B $\left(66^{\circ} \mathrm{C}\right)$, but most of the clones detected from Pond-A $\left(93^{\circ} \mathrm{C}\right)$ were affiliated with uncultured Sulfolobales, forming a phylotype ST8A1-12. In addition, the members of the genus Caldisphaera of the order Acidilobales were frequently detected from lower temperature ponds (Pond-B + Pond-D) but not detected from higher temperature ponds (Pond-A + Pond-C). This may be due to the growth temperature limit of the members of the genus Caldisphaera, which is $85^{\circ} \mathrm{C}$ [56].

3.8. Geochemistry and Archaeal Diversity or Groups Correlations. A matrix was created based on Pearson's correlation coefficients $(r)$ calculated from the Shannon-Weaver index, temperatures, and dissolved elemental concentrations at these four ponds (Table 4). Several dissolved elemental concentrations were statistically correlated with each other, but the archaeal diversity did not correlate with temperature and any dissolved elemental concentrations (significance level, $\alpha=0.10$ ). Total dissolved elemental concentration was strongly correlated with $\mathrm{S}, \mathrm{P}$, and $\mathrm{As}(P$ value $<0.05)$ and moderately correlated with $\mathrm{Fe}(P<0.10)$. Al and $\mathrm{S}$ were moderately correlated with each other. Principal components analysis showed that axes F1 and F2 accounted for $81.3 \%$ of the variation between sites; S, As, and Si contributed equally to $\mathrm{PC} 1$, while the archaeal diversity index contributed to PC2 (Figure 3). Pond-A and Pond-B were higher in total dissolved elemental concentration, and variations at Pond-A and Pond$\mathrm{B}$ appeared to be explained best by $\mathrm{S}$ and $\mathrm{As}$ of $\mathrm{PC1}$, whereas 


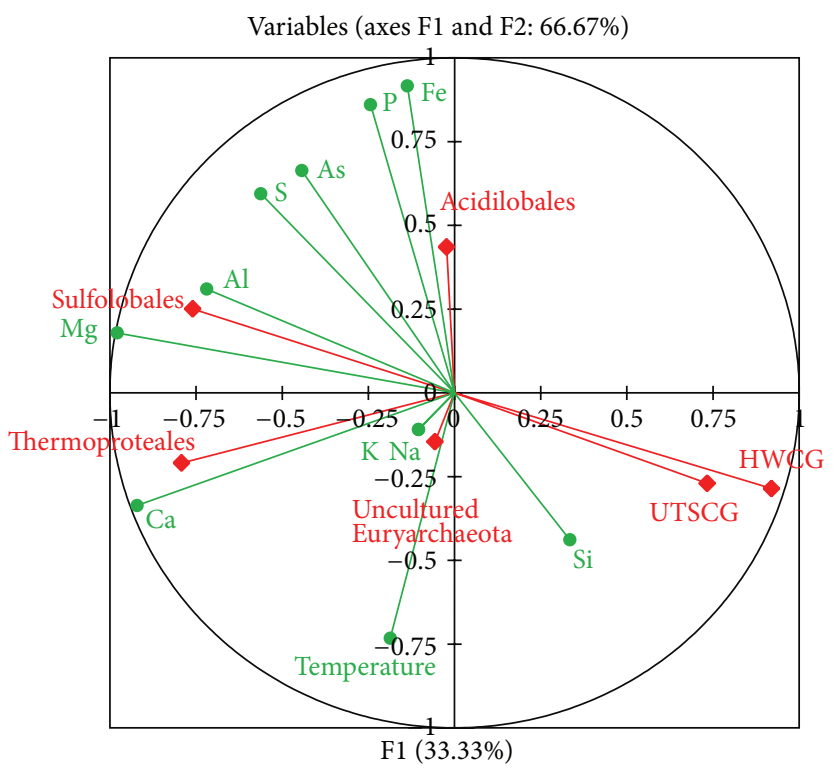

FIGURE 4: Canonical correlation analysis showing correlative relationships between environmental factors and proportions of individual archaeal groups. Archaeal groups were shown in abbreviations and rhombus. Environmental factors were shown in circle.

the variations at Pond-A with higher temperature were best explained by PC2.

Canonical correlation analysis showed that some archaeal groups strongly correlate with particular environmental factors, such as the Sulfolobales with $\mathrm{Al}$ and uncultured Euryarchaeota with Na and K, whereas UTSCG group was negatively correlated with $\mathrm{Al}(P<0.05)$ (Figure 4). The order Sulfolobales was also moderately correlated with $S$ $(P<0.10)$. Moreover, the order Acidilobales, UTSCG, and HWCG groups were moderately negatively correlated with temperature, $\mathrm{S}$, and $\mathrm{Mg}$, respectively. To date, the element requirements in archaea were conducted on certain cultured species and little was known of the uncultured archaea. However, the correlations between the uncultured archaeal groups and the dissolved elemental concentrations shown in this study could give more insights into how specific elements affect uncultured archaeal communities.

\section{Conclusion}

In this study, we have investigated the archaeal community structures of four distinct solfataric acidic hot springs in Kirishima, Japan. The species compositions and biodiversity were clearly different among the ponds showing different temperatures and dissolved elemental concentrations. Although other environmental factors also could have influenced on the archaeal community structures, the present study will be helpful in understanding the archaeal ecology in the solfataric acidic hot springs.

\section{Conflict of Interests}

The authors of this paper do not have a direct financial relation with the commercial identities mentioned herein that might lead to a conflict of interests.

\section{Acknowledgments}

The authors thank Mr. Fuchinoue and Mr. Wada for their support for field sampling. They also thank Professor Dr. Taguchi and Dr. Kok for their valuable suggestions to improve this paper.

\section{References}

[1] N. R. Pace, "Origin of life-facing up to the physical setting," Cell, vol. 65, no. 4, pp. 531-533, 1991.

[2] S. L. Miller and A. Lazcano, "The origin of life-did it occur at high temperatures?” Journal of Molecular Evolution, vol. 41, no. 6, pp. 689-692, 1995.

[3] J. A. Baross, "Do the geological and geochemical records of the early earth support the prediction from global phylogenetic models of a thermophilic cenancestor," in Thermophiles: The Keys to Molecular Evolution and the Origin of Life, pp. 3-18, Taylor \& Francis, Boca Raton, Fla, USA, 1998.

[4] N. R. Pace, "A molecular view of microbial diversity and the biosphere," Science, vol. 276, no. 5313, pp. 734-740, 1997.

[5] S. M. Barns, R. E. Fundyga, M. W. Jeffries, and N. R. Pace, "Remarkable archaeal diversity detected in a Yellowstone National Park hot spring environment," Proceedings of the National Academy of Sciences of the United States of America, vol. 91, no. 5, pp. 1609-1613, 1994.

[6] S. M. Barns, C. F. Delwiche, J. D. Palmer, and N. R. Pace, "Perspectives on archaeal diversity, thermophily and monophyly from environmental rRNA sequences," Proceedings of the National Academy of Sciences of the United States of America, vol. 93, no. 17, pp. 9188-9193, 1996.

[7] P. Hugenholtz, C. Pitulle, K. L. Hershberger, and N. R. Pace, "Novel division level bacterial diversity in a Yellowstone hot spring," Journal of Bacteriology, vol. 180, no. 2, pp. 366-376, 1998. 
[8] A. L. Reysenbach, M. Ehringer, and K. Hershberger, "Microbial diversity at $83^{\circ} \mathrm{C}$ in Calcite Springs, Yellowstone National Park: another environment where the Aquificales and "Korarchaeota" coexist," Extremophiles, vol. 4, no. 1, pp. 61-67, 2000.

[9] C. E. Blank, S. L. Cady, and N. R. Pace, "Microbial composition of near-boiling silica-depositing thermal springs throughout Yellowstone National Park," Applied and Environmental Microbiology, vol. 68, no. 10, pp. 5123-5135, 2002.

[10] D. R. Meyer-Dombard, E. L. Shock, and J. P. Amend, "Archaeal and bacterial communities in geochemically diverse hot springs of Yellowstone National Park, USA," Geobiology, vol. 3, no. 3, pp. 211-227, 2005.

[11] A. A. Perevalova, T. V. Kolganova, N. K. Birkeland, C. Schleper, E. A. Bonch-Osmolovskaya, and A. V. Lebedinsky, "Distribution of Crenarchaeota representatives in terrestrial hot springs of Russia and Iceland," Applied and Environmental Microbiology, vol. 74, no. 24, pp. 7620-7628, 2008.

[12] N. P. Burton and P. R. Norris, "Microbiology of acidic, geothermal springs of Montserrat: environmental rDNA analysis," Extremophiles, vol. 4, no. 5, pp. 315-320, 2000.

[13] L. M. Stout, R. E. Blake, J. P. Greenwood, A. M. Martini, and E. C. Rose, "Microbial diversity of boron-rich volcanic hot springs of St. Lucia, Lesser Antilles," FEMS Microbiology Ecology, vol. 70, no. 3, pp. 402-412, 2009.

[14] T. Kvist, B. K. Ahring, and P. Westermann, "Archaeal diversity in Icelandic hot springs," FEMS Microbiology Ecology, vol. 59, no. 1, pp. 71-80, 2007.

[15] K. Takai and Y. Sako, "A molecular view of archaeal diversity in marine and terrestrial hot water environments," FEMS Microbiology Ecology, vol. 28, no. 2, pp. 177-188, 1999.

[16] S. Kato, T. Itoh, and A. Yamagishi, "Archaeal diversity in a terrestrial acidic spring field revealed by a novel PCR primer targeting archaeal 16S rRNA genes," FEMS Microbiology Letters, vol. 319, no. 1, pp. 34-43, 2011.

[17] T. Kvist, A. Mengewein, S. Manzei, B. K. Ahring, and P. Westermann, "Diversity of thermophilic and non-thermophilic crenarchaeota at $80^{\circ}$ C, "FEMS Microbiology Letters, vol. 244, no. 1, pp. 61-68, 2005.

[18] P. Kanokratana, S. Chanapan, K. Pootanakit, and L. Eurwilaichitr, "Diversity and abundance of Bacteria and Archaea in the Bor Khlueng Hot Spring in Thailand," Journal of Basic Microbiology, vol. 44, no. 6, pp. 430-444, 2004.

[19] A. M. Childs, B. W. Mountain, R. O’Toole, and M. B. Stott, "Relating microbial community and physicochemical parameters of a hot spring: champagne pool, wai-o-tapu, New Zealand," Geomicrobiology Journal, vol. 25, no. 7-8, pp. 441-453, 2008.

[20] Z. Q. Song, J. Q. Chen, H. C. Jiang et al., "Diversity of Crenarchaeota in terrestrial hot springs in Tengchong, China," Extremophiles, vol. 14, no. 3, pp. 287-296, 2010.

[21] K. Goko, "Structure and hydrology of the Origi field, West Kirishima geothermal area, Kyushu, Japan," Geothermics, vol. 29, no. 2, pp. 127-149, 2000.

[22] T. Tsuyuki, "Geological study of hot springs in Kyushu, Japan (5). Some hot springs in the Kagoshima graben, with special references to thermal water reservoir. Reports of the Faculty of Science, Kagoshima University," Earth Science and Biology, vol. 2, pp. 85-101, 1969 (Japanese).

[23] R. Imura, T. Kobayashi, and C. C. S. Sentā, Geological Map of Kirishima Volcano, (Japanese), Geological Survey of Japan, 2001.

[24] K. Tamura, D. Peterson, N. Peterson, G. Stecher, M. Nei, and S. Kumar, "MEGA5: molecular evolutionary genetics analysis using maximum likelihood, evolutionary distance, and maximum parsimony methods," Molecular Biology and Evolution, vol. 28, pp. 2731-2739, 2011.

[25] S. F. Altschul, W. Gish, W. Miller, E. W. Myers, and D. J. Lipman, "Basic local alignment search tool," Journal of Molecular Biology, vol. 215, no. 3, pp. 403-410, 1990.

[26] J. D. Thompson, D. G. Higgins, and T. J. Gibson, "CLUSTAL $\mathrm{W}$ : improving the sensitivity of progressive multiple sequence alignment through sequence weighting, position-specific gap penalties and weight matrix choice," Nucleic Acids Research, vol. 22, no. 22, pp. 4673-4680, 1994.

[27] S. H. Hurlbert, "The nonconcept of species diversity: a critique and alternative parameters," Ecology, vol. 52, pp. 577-586, 1971.

[28] G. Stirling and B. Wilsey, "Empirical relationships between species richness, evenness, and proportional diversity," American Naturalist, vol. 158, no. 3, pp. 286-299, 2001.

[29] C. E. Shannon, W. Weaver, R. E. Blahut, and B. Hajek, The Mathematical Theory of Communication, University of Illinois Press, Urbana, Ill, USA, 1949.

[30] E. H. Simpson, "Measurement of diversity," Nature, vol. 163, no. 4148, article 688, 1949.

[31] R. K. Colwell, 2006, EstimateS: Statistical estimation of species richness and shared species from samples, Version 8 , http://purl.oclc.org/estimates.

[32] E. C. Pielou, "Association tests versus homogeneity tests: their use in subdividing quadrats into groups," Vegetatio, vol. 18, no. 1-6, pp. 4-18, 1969.

[33] A. Chao, "Estimating the population size for capture-recapture data with unequal catchability," Biometrics, vol. 43, no. 4, pp. 783-791, 1987.

[34] A. Chao, W. H. Hwang, Y. C. Chen, and C. Y. Kuo, "Estimating the number of shared species in two communities," Statistica Sinica, vol. 10, no. 1, pp. 227-246, 2000.

[35] I. J. Good, "The population frequencies of species and the estimation of population parameters," Biometrika, vol. 40, pp. 237-264, 1953.

[36] D. R. Singleton, M. A. Furlong, S. L. Rathbun, and W. B. Whitman, "Quantitative comparisons of 16S rRNA gene sequence libraries from environmental samples," Applied and Environmental Microbiology, vol. 67, no. 9, pp. 4374-4376, 2001.

[37] H. Kimura, K. Mori, T. Tashiro et al., "Culture-independent estimation of optimal and maximum growth temperatures of archaea in subsurface habitats based on the $\mathrm{G}$ plus $\mathrm{C}$ content in 16 S sequences," Geomicrobiology Journal, vol. 27, no. 2, pp. 114$122,2010$.

[38] T. Itoh, K. I. Suzuki, P. C. Sanchez, and T. Nakase, "Caldivirga maquilingensis gen. nov., sp. nov., a new genus of rod- shaped crenarchaeote isolated from a hot spring in the Philippines," International Journal of Systematic Bacteriology, vol. 49, no. 3, pp. 1157-1163, 1999.

[39] T. Itoh, K. I. Suzuki, and T. Nakase, "Vulcanisaeta distributa gen. nov., sp. nov., and Vulcanisaeta souniana sp. nov., novel hyperthermophilic, rod-shaped crenarchaeotes isolated from hot springs in Japan," International Journal of Systematic and Evolutionary Microbiology, vol. 52, no. 4, pp. 1097-1104, 2002.

[40] W. Zillig, K. O. Stetter, and S. Wunderl, "The Sulfolobus"Caldariella" group: taxonomy on the basis of the structure of DNA-dependent RNA polymerases," Archives of Microbiology, vol. 125, no. 3, pp. 259-269, 1980.

[41] G. Huber, C. Spinnler, A. Gambacorta, and K. O. Stetter, "Metallosphaera sedula gen. and sp. nov. represents a new genus of 
aerobic, metal-mobilizing, thermoacidophilic archaebacteria," Systematic and Applied Microbiology, vol. 12, pp. 38-47, 1989.

[42] A. Segerer, A. Neuner, J. K. Kristjansson, and K. O. Stetter, "Acidianus infernus gen. nov., sp. nov., and Acidianus brierleyi comb. nov.: facultatively aerobic, extremely acidophilic thermophilic sulfur-metabolizing archaebacteria," International Journal of Systematic Bacteriology, vol. 36, no. 4, pp. 559-564, 1986.

[43] T. Itoh, K. Suzuki, P. C. Sanchez, and T. Nakase, "Caldisphaera lagunensis gen. nov., sp. nov., a novel thermoacidophilic crenarchaeote isolated from a hot spring at Mt Maquiling, Philippines," International Journal of Systematic and Evolutionary Microbiology, vol. 53, no. 4, pp. 1149-1154, 2003.

[44] H. Huber and K. O. Stetter, "Order III. Sulfolobales," in Bergey's Manual of Systematic Bacteriology, J. T. Staley, M. P. Bryant, E. N. Pfenning, and J. G. Holt, Eds., vol. 1, pp. 198-210, Williams and Wilkins, Baltimore, Md, USA, 2nd edition, 2001.

[45] M. O. Schrenk, D. S. Kelley, J. R. Delaney, and J. A. Baross, "Incidence and diversity of microorganisms within the walls of an active deep-sea sulfide chimney," Applied and Environmental Microbiology, vol. 69, no. 6, pp. 3580-3592, 2003.

[46] T. Nunoura, H. Hirayama, H. Takami et al., "Genetic and functional properties of uncultivated thermophilic crenarchaeotes from a subsurface gold mine as revealed by analysis of genome fragments," Environmental Microbiology, vol. 7, no. 12, pp. 19671984, 2005.

[47] T. Itoh, K. I. Suzuki, and T. Nakase, "Thermocladium modestius gen. nov., sp. nov., a new genus of rod-shaped, extremely thermophilic crenarchaeote," International Journal of Systematic Bacteriology, vol. 48, no. 3, pp. 879-887, 1998.

[48] E. S. Boyd, R. A. Jackson, G. Encarnacion et al., "Isolation, characterization, and ecology of sulfur-respiring Crenarchaea inhabiting acid-sulfate-chloride-containing geothermal springs in Yellowstone National Park," Applied and Environmental Microbiology, vol. 73, no. 20, pp. 6669-6677, 2007.

[49] K. Takai and K. Horikoshi, "Genetic diversity of archaea in deep-sea hydrothermal vent environments," Genetics, vol. 152, no. 4, pp. 1285-1297, 1999.

[50] F. Inagaki, K. Takai, H. Hirayama, Y. Yamato, K. H. Nealson, and K. Horikoshi, "Distribution and phylogenetic diversity of the subsurface microbial community in a Japanese epithermal gold mine," Extremophiles, vol. 7, no. 4, pp. 307-317, 2003.

[51] C. Vetriani, H. W. Jannasch, B. J. Macgregor, D. A. Stahl, and A. L. Reysenbach, "Population structure and phylogenetic characterization of marine benthic Archaea in deep-sea sediments," Applied and Environmental Microbiology, vol. 65, no. 10, pp. 4375-4384, 1999.

[52] K. Takai, D. P. Moser, M. DeFlaun, T. C. Onstott, and J. K. Fredrickson, "Archaeal diversity in waters from deep South African gold mines," Applied and Environmental Microbiology, vol. 67, no. 12, pp. 5750-5760, 2001.

[53] A. Teske, K. U. Hinrichs, V. Edgcomb et al., "Microbial diversity of hydrothermal sediments in the Guaymas Basin: evidence for anaerobic methanotrophic communities," Applied and Environmental Microbiology, vol. 68, no. 4, pp. 1994-2007, 2002.

[54] E. F. DeLong, "Archaea in coastal marine environments," Proceedings of the National Academy of Sciences of the United States of America, vol. 89, no. 12, pp. 5685-5689, 1992.

[55] G. Jurgens and A. Saano, "Diversity of soil Archaea in boreal forest before, and after clear-cutting and prescribed burning," FEMS Microbiology Ecology, vol. 29, no. 2, pp. 205-213, 1999.
[56] M. I. Prokofeva, N. A. Kostrikina, T. V. Kolganova et al., "Isolation of the anaerobic thermoacidophilic crenarchaeote Acidilobus saccharovorans sp. nov. and proposal of Acidilobales ord. nov., including Acidilobaceae fam. nov. and Caldisphaeraceae fam. nov," International Journal of Systematic and Evolutionary Microbiology, vol. 59, no. 12, pp. 3116-3122, 2009. 

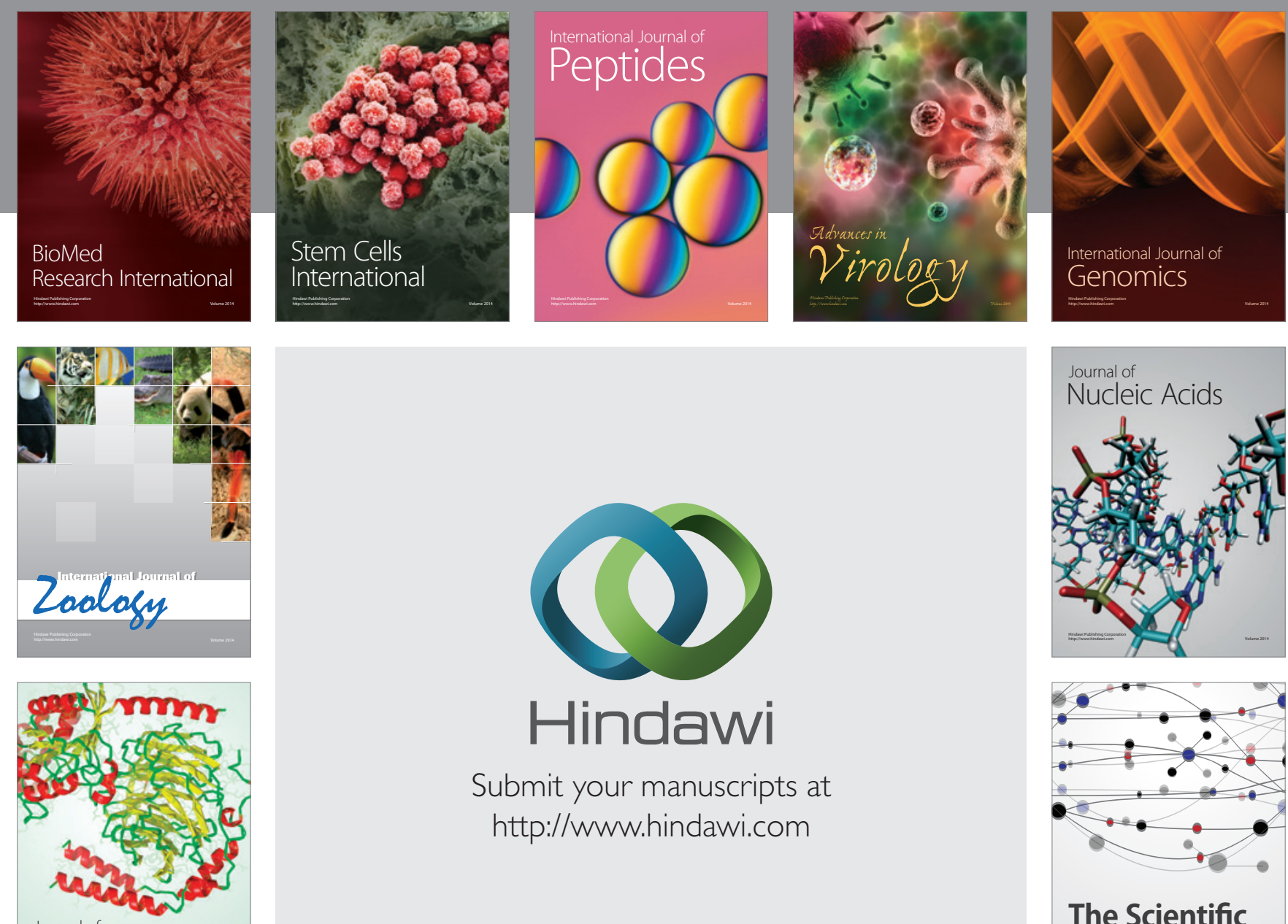

Submit your manuscripts at

http://www.hindawi.com

Journal of
Signal Transduction
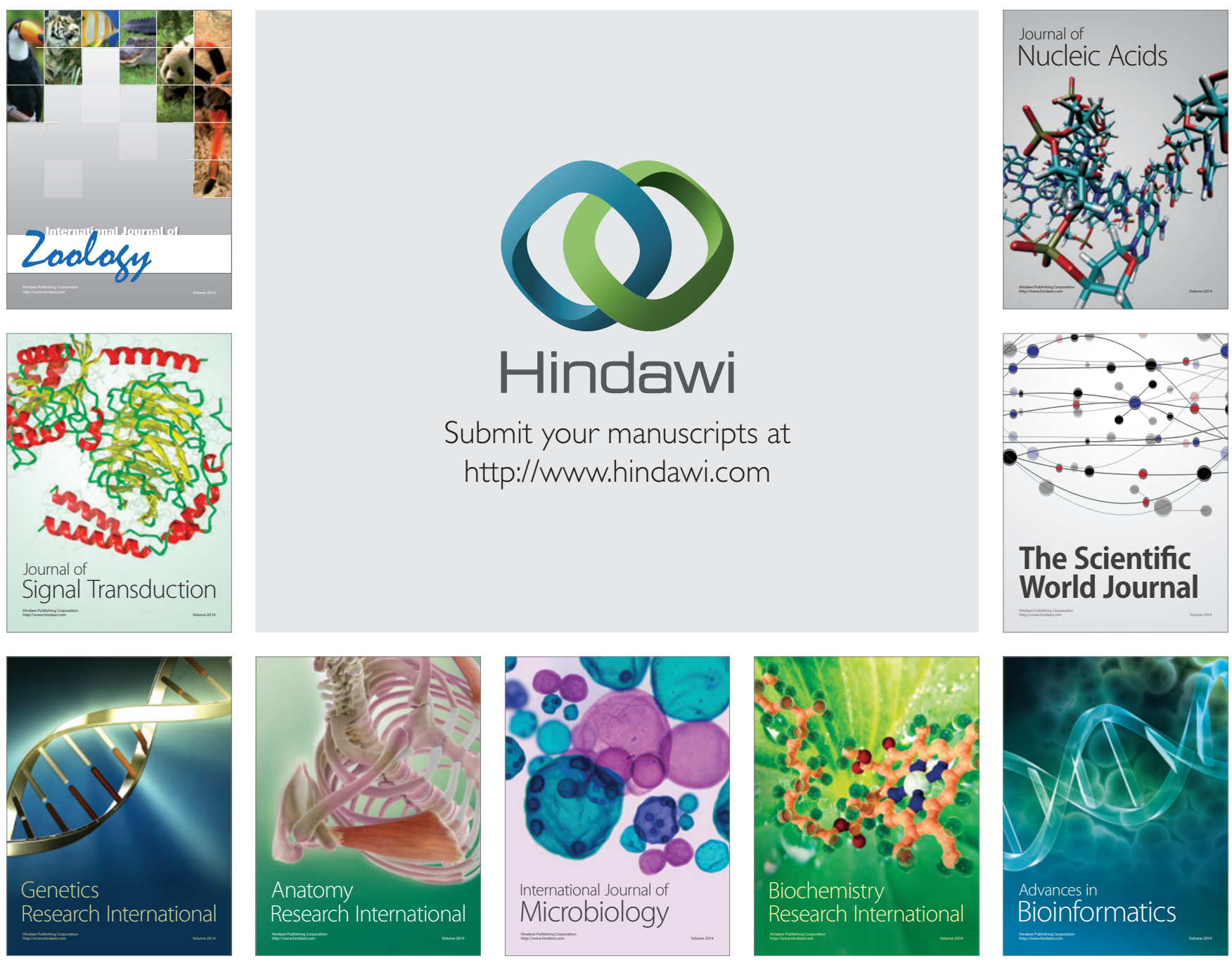

The Scientific World Journal
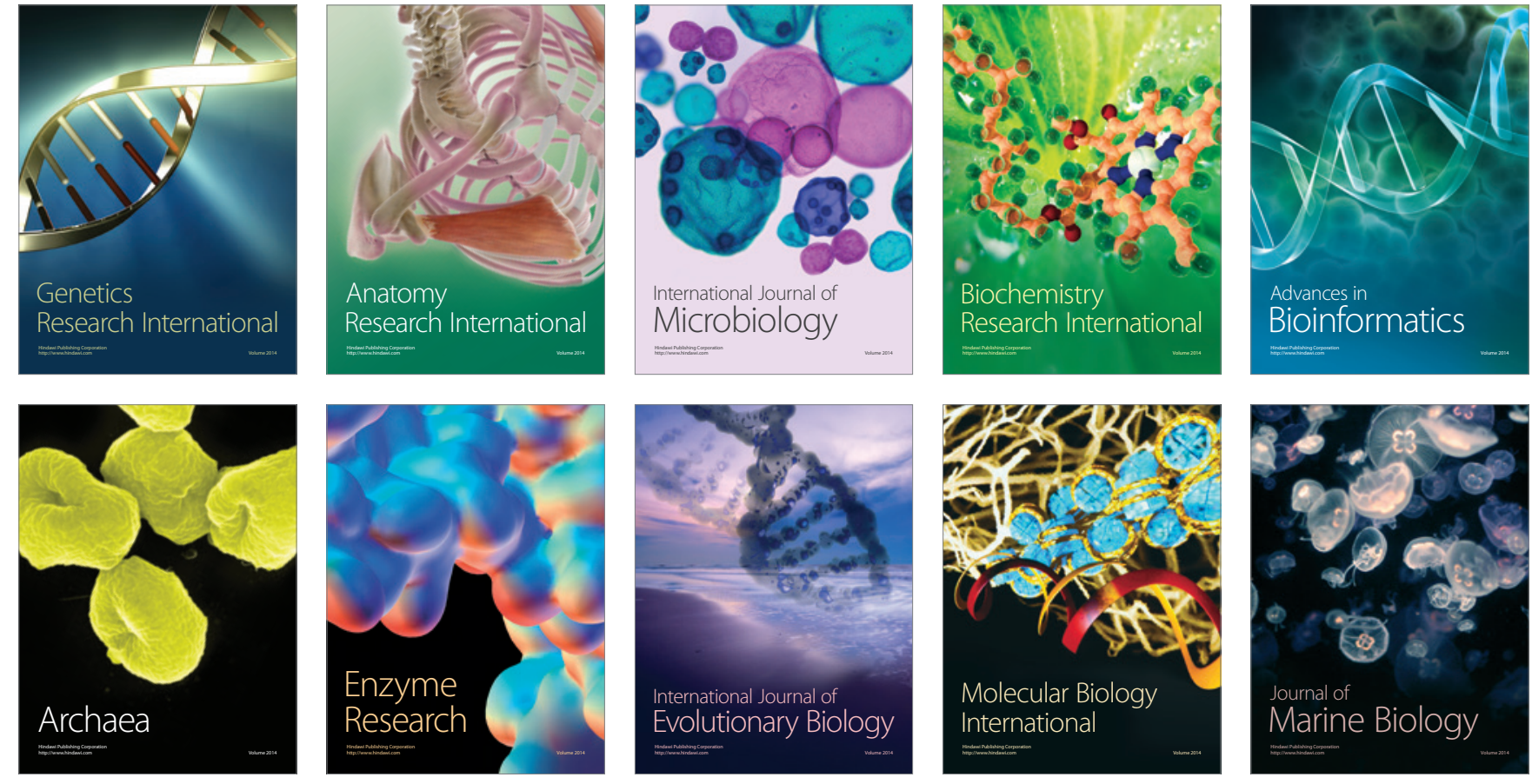